Copyright (C) 2021 by Cherkas Global University

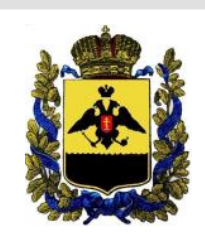

Published in the USA

Bylye Gody

Has been issued since 2006.

E-ISSN: $2310-0028$

2021. 16(4): 1800-1813

DOI: $10.13187 /$ bg.2021.4.1800

Journal homepage:

https://bg.cherkasgu.press

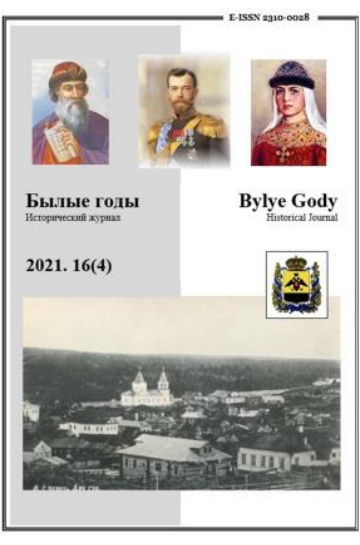

\title{
The System of Public Education in the Erivan Province in 1849-1917. Part 1
}

Anvar M. Mamadaliev a, b, *, Varvara V. Bogdan c, Natalia V. Svechnikova d, Aleksandr N. Volkov e

a Cherkas Global University, Washington, USA

b Volgograd State University, Volgograd, Russian Federation

c Southwest State University, Kursk, Russian Federation

d Plekhanov Russian University of Economics, Moscow, Russian Federation

e Sochi State University, Sochi, Russian Federation

\begin{abstract}
A series of three articles is devoted to the study of the education system in the Erivan province of the Russian Empire in the period from 1849 to 1917. This article is the first (and a kind of introductory) part, which analyzes the period from 1849 (the year of the formation of the province) to 1884 , as well as the sources and historiography of the issue we are researching.

The article examines the natural and climatic, social and economic features of the region, as well as the process of formation of the education system of the province and its integration into the all-Russian. The types of educational institutions (secondary, lower, primary), as well as the library fund of secondary educational institutions (as one of the important criteria for the development of this type of institution) are analyzed separately.

The main source was the reports of the trustees of the Caucasian Educational District, which provide the detailed statistical material on the activities of each type of institution. Also, the Regulations "On the Caucasian Educational District and educational institutions" of October 29, 1853, Acts of the Caucasian Geographical Commission, the Collection of Laws of the Russian Empire, etc. were used as sources.

The work also provides a brief bibliographic analysis of pre-revolutionary, soviet and modern works devoted to the development of the education system in the Erivan province as part of the Russian Empire.

Based on the research results, it was concluded that before the adoption of the Regulation of 1853, the education system in the Erivan province was objectively extremely weak: only 4 lower-level educational institutions operated. By the end of 1884, there were 3 secondary, 3 lower and 14 primary educational institutions in the province. At the same time, in comparison with the coastal Black Sea provinces (Tiflis, Kutaisi, Black Sea), the number of educational institutions per capita was still small, and the education system, respectively, undeveloped. This can be explained by the prevalence of traditional crafts, which did not place additional demands on learning.
\end{abstract}

Keywords: system of public education, Erivan province, Caucasian educational district, 1849-1884.

\section{1. Введение}

Как известно, развитие и интеграция образовательной системы Кавказа в общероссийское образование следует назвать непростым процессом (более подробно см., напр., Shevchenko et al., 2016; Gogitidze, Shiukashvili, 2016) в силу ряда причин, главными из которых было отсутствие письменности у многих коренных народов, а также недавнее вхождение территорий в состав Российской империи (конец XVIII - середина XIX вв.). Важнейшими задачами русского правительства были не только активная русификация региона (т.е. внедрение русскоязычной письменности и соответствующего

\footnotetext{
${ }^{*}$ Corresponding author

E-mail addresses: anvarm@mail.ru (A.M. Mamadaliev)
} 
документооборота), но и сохранение, и даже создание письменности некоторым народам Кавказа местных этнических орфографических и лингвистических элементов, которые обобщенно в современной науке принято называть «региональным компонентом» (подробно о проблеме см. Shevchenko et al., 2016). Активная и, безусловно, плодотворная работа образовательной администрации Кавказского учебного округа в лице ее попечителей (Василий Николаевич Семенов, 1848-1852 годы попечительства; Александр Павлович Николаи, 1852-1860 гг.; Януарий Михайлович Неверов, 1864-1878 гг.; Кирилл Петрович Яновский, 1878-1901 гг.; Михаил Ромуальдович Завадский, 1901-1906 гг.; Николай Федорович Рудольф, 1906-1917 гг.) привела к тому, что к «периоду упадка империи процесс интеграции системы образования на Кавказе в общероссийскую фактически был завершен» (см., напр., Cherkasov, 2011: 148).

В этой (первой) части нашего исследования развития системы образования Эриванской губернии делается анализ становления данной народной образовательной системы после ее выделения в отдельную административную единицу в 1849 году, типов учреждений (средних, низших и начальных), а также библиотечного фонда средних учебных заведений как одного из важных критериев качества получаемого образования.

\section{2. Материалы и методы}

Источниками нашей работы стали статистические документы администрации Кавказского учебного округа, указы, положения и прочие нормативные акты, регулировавшие деятельность системы образования. В качестве материалов были использованы дореволюционные статистические сборники, статьи, монографии, так или иначе касающиеся проблемы нашего исследования, а также труды советских и современных ученых.

С учетом того, что данная статья является первой в серии, считаем целесообразным акцентировать внимание на анализе используемых источников.

Основным источником серии работ по исследованию системы образования Эриванской губернии стали отчеты попечителей. В хронологических рамках этой статьи мы использовали оказавшийся в нашем распоряжении отчет за 1884 год, составленный попечителем Кавказского учебного округа Кириллом Петровичем Яновским (Отчет, 1884).

В целом, отчеты попечителей являются ценным материалом для изучения учебного дела на территории Кавказа. Во-первых, они весьма объемные и глубокие: каждый отчет содержит от 600 до 1200 страниц машинописного текста. Во-вторых, информация в них четко структурирована: в первой части идет текстовое описание состояния всех имеющихся учебных заведений, а также достижений, которые произошли за отчетный год. В-третьих, приложения к каждому отчету содержат таблицы с исчерпывающей информацией по административному, педагогическому и ученическому составу учреждений образования (по сословному, конфессиональному и другим критериям), финансированию и расходам, организации учебной деятельности (вплоть до количества пропущенных уроков) и многое другое. Можно сказать, что каждый из отчетов является фундаментальным трудом, значение которого для историка невозможно переоценить.

«Статистическое описание Закавказского края» О.С. Евецкого, изданное в Санкт-Петербурге в 1835 году, хотя и выходит за хронологические рамки данной работы, тем не менее дает хорошее понимание географии, экономики и этнического состава Кавказа середины XIX века, так как является весьма глубоким для своего времени исследованием (Статистическое описание, 1835).

Огромное значение для понимания организационных особенностей Кавказского учебного округа в целом имеет Положение от 29 октября 1853 года «О Кавказском учебном округе и учебных заведениях», подписанное императором Николаем I. Закон был принят прежде всего для централизации управления системой образования на Кавказе, а также для обеспечения ее гармоничного интегрирования в образовательную систему Российской империи в целом, ибо, как указывалось выше, до присоединения к России в образовательной сфере региона имелся целый ряд проблем. Положение создало четкую иерархию не только административного состава системы образования на Кавказе, но и учреждений - их тип (принадлежность к низшему, начальному или среднему ступеням образования), количество классов, пансионов при них (и даже регламентировало деятельность частных репетиторов и гувернеров), возрастной ценз для каждого учреждения (и класса), стоимость платы за обучение, размер зарплат педагогического и административного штата, перечень предметов для каждого класса и типа учебного заведения и мн. др. Положение от 1853 года действовало фактически (и юридически) вплоть до развала империи (Положение от 29.10.1853).

Для понимания социальной, экономической, этнографической и географической обстановки значительный интерес представляет ряд источников, описывающих указанные сферы.

К таковым следует отнести исследования Н.И. Воронова - фундаментальный труд «Сборник статистических сведений о Кавказе», изданный в Тифлисе в 1869 году (Сборник статистических сведений о Кавказе, 1896), а также «Черноморские письма», опубликованные в «Русском вестнике» (Воронов, 1857). 
В числе источников хотелось бы отметить и многотомный труд под названием «Акты, собранные Кавказской комиссией», изданные в Тифлисе в 1881, куда вошел пласт ценных этнологических, географических, социальных и экономических сведений о Кавказе (АКАК).

Особый интерес представляет масштабный и очень глубокий труд Н.К. Зейдлица «Свод статистических данных о населении Закавказья, с полным алфавитным указателем городов и деревень края», также изданный в Тифлисе в 1894 году. Исследование включает в себя 9 томов подробнейшего описания всех сфер жизни Кавказа (Сборник сведений о Кавказе, 1871-1885). В 1894 году в дополнение к нему вышел «Свод статистических данных о населении Закавказья, с полным алфавитным указателем городов и деревень края» с десятью тысячей наименований населенных пунктов, этносов, терминов и пр. (Зейдлиц, 1894).

Краткую общую информацию как о регионе (Эриванской губернии) может дать известная Энциклопедия Брокгауза и Ефрона (Брокгауз-Ефрон, 1896).

Важнейшим источником по истории дореволюционной России ХХ в. является Первая Всеобщая перепись населения Российской империи 1897 г., изданная в Санкт-Петербурге Н.А. Тройницким, которая позволяет понять особенности этнических и демографических процессов, происходивших на юге империи на рубеже веков (Всеобщая перепись населения, 1897).

Исчерпывающую информацию о нормативном регулировании сферы образования дают нормативные акты, собранные в «Полном собрании законов Российской Империи». В контексте обозначенных в нашем исследовании хронологических границ мы обращались ко Второму (18251881 годы) и Третьему (1881-1913 годы) собраниям (ПСЗРИ).

Из комплексных дореволюционных источников, посвященных исследованию сферы образования, можно упомянуть «Исторический обзор деятельности Министерства народного просвещения на протяжении XIX века (1802-1902 годы)», составленный С.В. Рождественским и изданный в 1902 году (Исторический обзор, 1902).

Что касается методологии, то в работе использовался комплекс методов исследования как традиционных исторических, так и нетрадиционных исторических и общенаучных.

Из традиционных методов исторического исследования применялся историко-системный (анализ развития системы образования Эриванской губернии в неотрывной связи с экономической, социальной, демографической и политической обстановкой), историко-типологический (определение типов учебных заведений в соответствии с нормативным регулированием в Российской империи), историко-генетический (выявление результатов внедрения тех или иных положений в образовательную политику региона), историко-сравнительный метод (сравнивалось состояние системы образования в начале и в конце исследуемого хронологического периода; также данный метод использовался при сравнении системы образования Әриванской губернии с аналогичными в других губерниях - Черноморской, Тифлисской, Кутаисской).

Из нетрадиционных методов исторического исследования в нашей работе использовался статистический метод (математический/количественный анализ заведений, учащихся в них, объем финансирования и расходов, количество томов библиотечного фонда и пр.).

Из общенаучных методов исследования применялись синтез, анализ (научной литературы, источников, системный анализ) и др. Комплекс примененных методов позволил всецело и объективно воссоздать картину народного образования в Әриванской губернии и выявить ее характерные и специфические особенности в сфере образовательной деятельности.

\section{3. Обсуждение}

Развитие системы народного образования в Әриванской губернии мало освещалось в научной литературе; глубоких научно-исторических трудов по этой проблематике мы не нашли, что, собственно, и обуславливает новизну нашего исследования. Вместе с тем комплексных работ, которые посвящены системе образования на Кавказе в целом, на современном этапе развития исторической науки уже немало, причем такая тенденция появилась именно в последние годы. В частности, отдельно (и достаточно глубоко) анализируются различные дирекции Кавказского учебного округа: Тифлисской губернии (см, напр., Mamadaliev et al., 2020a; Mamadaliev et al., 202ob; Mamadaliev et al., 2020c; Mamadaliev et al., 2020d и др.), Кутаисской губернии (см, напр., Mamadaliev et al., 2021e; Mamadaliev et al., 2021f; Mamadaliev et al., 2021g и др.), территории Кубанского казачьего войска (см., напр., Molchanova et al., 2019; Molchanova et al., 2019a; Molchanova et al., 2020 и др.), Ставропольской губернии (см., напр., Natolochnaya et al., 2020; Natolochnaya et al., 2020a; Natolochnaya et al., 2020b и др.), Черноморской губернии (см., напр., Cherkasov et al., 2020; Cherkasov et al., 2020а и др.), Карской области (см., напр., Magsumov et al., 2020; Magsumov et al., 2020а и др.), Терской области (см., напр., Cherkasov et al., 2020b и др.) (хронологические рамки исследований: с момента основания соответствующих административных единиц до распада Российской империи в 1917 году).

Из зарубежных исследований в рамках нашего исследования представляют интерес работы А.А. Богоявленского, посвященные развитию библиотечного дела в начальных училищах Кавказского учебного округа (Богоявленский, 1911; Богоявленский, 1912а; Богоявленский, 1912b), П. Зажаева о работе городских училищ в России и на Кавказе, созданных в соответствии с Положением 1872 года 
(Зажаев, 1909), Л. Модзалевского, анализирующего процесс развития образования на Кавказе в 18021880 годах (Модзалевский, 1880) и др.

Среди советских работ отметим «Материалы по истории осетинского народа: Сборник документов по истории завоевания осетин русским царизмом», составленные В.С. Гальцевым (Орджоникидзе, 1942) (Материалы по истории, 1942), а также сборник статей «Народное образование и педагогическая мысль России кануна и начала империализма (Малоисследованные проблемы и источники)», вышедший в Москве в 1980 году под редакцией Э.Д. Днепрова (Народное образование, 1980).

Среди комплексных работ современного периода отметим работы А.А. Черкасова, посвященные общероссийской системе основного образования (Cherkasov, 2011), O.В. Натолочной, Н.И. Крюковой, С.И. Буслаева об общих вопросах процесса развития народного образования на Кавказе в начале XX века (1905-1907 гг.) (Natolochnaya et al., 2016). Т.А. Магсумов, С.Ф. Артемова, О.В. Устинова, Е.В. Видищева дали общую характеристику процессу становления народного образования на Кавказе в 1850-е годы и проанализировали особенности его интеграции в общероссийское образование (Magsumov et al., 2018). Вопросы функционирования высшей школы на Кавказе, в том числе и в дореволюционный период, рассмотрели О.В. Натолочная, Н.В. Мику, Т.Е. Зульфугарзаде, А. Медико (Natolochnaya et al., 2018). Общие вопросы процесса создания системы народного образования на Кавказе освещены Н.А. Шевченко, Е.В. Ведищевой, О.В. Емельяновой (Shevchenko et al., 2016). Е.И. Кобахидзе исследует законодательство 1840-1870-х гг. в области образования как фактор интеграции кавказской школы в российскую систему народного просвещения (Кобахидзе, 2015). Значительный интерес представляет фундаментальный труд Л.С. Гатаговой «Правительственная политика и народное образование на Кавказе в XIX в.» (Гатагова, 1993).

Как было указано выше, отдельные регионы Кавказа в последние годы были весьма подробно рассмотрены современными исследователями.

А.А. Черкасовым, Л.А. Королевой, С.Н. Братановским, Л.Г. Зимовец была исследована система народного образования на территории Черноморской губернии (Cherkasov et al., 2020; Cherkasov et al., 2020а; Cherkasov et al., 2020b). T.А. Магсумов, А.А. Королев, М.А. Пономарева, Т.Е. Зульфугарзаде исследовали процесс создания системы народного образования в Карской области и проблемы ее интеграции в общероссийскую систему образования, проанализировав число учащихся, их конфессиональный, сословный состав и пр. (Magsumov et al., 2020; Magsumov et al., 2020а). Нами были исследованы аналогичные элементы системы народного образования в Тифлисской (Mamadaliev et al., 2020a; Mamadaliev et al., 2020b; Mamadaliev et al., 2020c; Mamadaliev et al., 2020d) и Кутаисской (Mamadaliev et al., 2021e; Mamadaliev et al., 2021f; Mamadaliev et al., 2021g) губерниях. В.С. Молчанова, Л.Л. Баланюк, Е.В. Видищева, И.И. Потапова сделали анализ развития начального образования в дореволюционный период (1803-1917 гг.) на территории Кубанского казачьего войска (Molchanova et al., 2019; Molchanova et al., 2019a; Molchanova et al., 2020). Элементы системы образования Ставропольской губернии и процесс ее интеграции в общероссийскую оказался в сфере научных интересов О.В. Натолочной, Л.Г. Зимовец, Р.М. Алалуева, В.А. Свешникова, В.Г. Иванцова, Ю.Н. Макарова (Natolochnaya et al., 2020; Natolochnaya et al., 2020a; Natolochnaya et al., 2020b).

Однако фундаментальное исследование системы образования Эриванской губернии осталось за рамками указанных трудов. Наша работа, состоящая из серии трех статей, призвана восполнить этот пробел.

\section{4. Результаты}

Географические рамки исследования ограничены Эриванской губернией (1849-1917), которая была образована 9 июня 1849 года указом императора Николая I: «для успешнейшего движения дел и удобнейшего управления образовать в Закавказском крае еще новую губернию» (ПСЗРИ, 1881: ст. 23303). Территориально она находилась «в центральной части южного Закавказья, между $41^{\circ} 7^{\prime}$ и $38^{\circ} 52^{\prime}$ северной широты и $60^{\circ} 56^{\prime}$ и $63^{\circ} 54^{\prime}$ восточной долготы, образует неправильный, вытянутый с северо-запада на юговосток параллелограмм; граничит: на севере - с Тифлисской и Елисаветпольской губерниями, на востоке - с Елисаветпольской губернией, на западе - с Карской областью, на юге - с Эрзерумским вилайетом Азиатской Турции и с Адербейджанской провинцией Персии. Длина государственной границы с Персией 246 1/2 верст, с Турцией - 130 верст; общее протяжение границ Э. губернии 1052 1/2 версты. Э. губерния занимает 24454,4 кв. верст или 27830 кв. км (по Стрельбицкому). Жителей 804757. 7 уездов: Новобаязетский, Нахичеванский, Александропольский, Сурмалинский, Эриванский, Эчмиадзинский и Шаруро-Даралагезский; самый большой из них - Новобаязетский, самый малый - ШаруроДаралагезский» (Брокгауз-Ефрон, 1904: 10).

Административным центром был город Эривань с населением (согласно Первой Всеобщей переписи населения Российской империи 1897 г.) в 29006 чел. Следует отметить, что в отличие, к примеру, от Тифлисской губернии, где административная столица региона по численности населения была в разы больше, чем другие города, в Эриванской губернии дело обстояло иначе: наиболее крупным городом был Александрополь с населением в 30616 чел. На третьем и четвертом местах были г. Нахичевань и г. Ново-Баязет (соответствующие названию административных центров уездов), которые фактически были равны по численности (8 790 и 8486 чел. соответственно). Далее 
располагались г. Вагаршапат Эчмиадзинского уезда -5 267 чел., селение Игдыр Сурмалинского уезда - 4680 чел. (современная территория Турции) и селение Баш-Норашен Шаруро-Даралагезского уезда - 867 чел. (Всеобщая перепись населения, 1897: 1).

Этническое большинство (52,08 \%), по данным Первой Всеобщей переписи населения Российской империи 1897 г., составляли представители армянской нации (Всеобщая перепись населения, 1897: 55).

Хронологические рамки всей серии статей, посвященной развитию системы образования Эриванской губернии, составляют 1849-1917 годы: 1849-й - является годом основания губернии, 1917й - датой развала Российской империи. Однако анализ столь большого периода в рамках одной публикации был бы весьма громоздким, поэтому целесообразным представляется разделение исследования на три части:

1. 1846-1885 годы - период становления системы образования Эриванской губернии и интеграция ее в общероссийскую до демографического «взрыва».

2. 1885-1907 годы - период количественного увеличения образовательных учреждений (так называемое развитие «вширь»). При исследовании сферы образования в данный период особый упор делается на влияние сильнейшего демографического роста в южных регионах России (и особенно на Кавказе).

3. 1908-1917 годы - период как количественного, так и качественного (так называемое развитие «вглубь») улучшения системы образования, связанное с принятием Закона от 3 мая 1908 года, который значительно расширил государственные ассигнования, выделяемые на народное образование и, по нашему мнению, в значительной мере изменил вектор развития образовательной сферы Российской империи (более подробно см. Mamadaliev et al., 2020d).

Таким образом, хронологические рамки данной статьи, т.е. первой части в серии работ, ограничены 1849-1885 годами.

В 1850-х гг. образовательные заведения Эриванской губернии административно подчинялись директору Кутаисской дирекции училищ - чиновнику VI класса по «Табели о рангах» с годовой заработной платой в 1000 руб., к которым прибавлялись с 300 руб. «столовых» ${ }^{\text {и }} 300$ руб. «квартирных» ${ }^{2}$ в год. При директоре находились бухгалтер (чиновник XII класса) и письмоводитель (чиновник XIV класса) с зарплатами в 300 руб./год и 90 руб. «квартирных», но без бюджетных расходов на пропитание.

Положение от 1853 года определяет несколько учебных заведений в губернии, количество и тип которых мы и будем считать отправной точкой (Положение от 29.10.1853: 30):

1. Уездное училище в г. Эривань (совр. г. Ереван, Армения) с тремя высшими классами. В личном составе заведения находились штатный смотритель - чиновник (гражданский служащий) VIII класса с зарплатой в 700 руб./год, учителя наук и учитель «приготовительного» (подготовительного - Авт.) класса (чиновники XII класса с зарплатой в 40о руб./год), а также законоучителя (преподаватели теологии) православного, армяно-григорианского и мусульманского вероисповедания (чиновники без требования к классу в «Табели о рангах» и с зарплатой в 200 руб./год) (Положение от 29.10.1853: 87).

Следует отметить, что фактически тарификация заработных плат была едина для всего учебного округа.

2. Уездное училище в г. Александрополь (совр. г. Гюмри, Армения). Руководитель училища совмещал должности смотрителя и одного из двух учителей наук; также имелся учитель «приготовительного» класса и отдельно - учитель греческого языка (чиновник XII класса с зарплатой в 150 руб./год). Должности законоучителей были аналогичными с вышеуказанным училищем (Положение от 29.10.1853: 88-89).

3. Уездное училище в г. Нахичевань (ныне находится на территории Азербайджана). По штату 6 сотрудников (без детализации заработных плат и должностей) (Положение от 29.10.1853: 88).

4. Первоначальное училище в г. Ново-Баязет (совр. г. Гавар, Армения). Штат включал в себя всего двух человек: смотрителя (руководителя заведения) с совмещением должности учителя русского языка и арифметики, учителя армянского языка с совмещением должности законоучителя армяно-григорианского вероисповедания. Смотритель училища с совмещением должности учителя арифметики и русского языка приравнивался к чиновникам Х разряда и в год зарабатывал 400 руб., законоучитель армяно-григорианского вероисповедания при совмещении должности учителя армянского языка (без разряда) - 150 руб. (Положение от 29.10.1853: 90-91). Наем помещения и прислуги обходился бюджету в 300 руб./год.

Как видим, в сравнении с «передовой» Тифлисской губернией (и даже с «непередовыми» другими территориями, в частности Кутаисской или Черноморской губерниями) количество образовательных учреждений было мало, что говорит о весьма отсталой системе образования в нижней точке хронологических рамок исследования.

\footnotetext{
1 T.е. оплата питания.

2 Т.е. оплата аренды жилья.
} 
Исследуя систему образования Эриванской губернии, мы не можем обойти вниманием один из фундаментальных историко-статистических трудов - энциклопедический словарь Ф.А. Брокгауза и И.А. Ефрона, который мог бы дать нам общее представление о развитии образования в губернии к началу XX века (по аналогии с другими регионами, в частности Тифлисской или Кутаисской губерниями). Однако никакой информации об образовании в Эриванской губернии в данном источнике нет! Это очередной раз подтверждает факт того, что сфера образования была здесь развита крайне слабо.

Объяснение этому может дать косвенная информация из той же энциклопедии: «Население Э. губернии (429689 мужчин, 375068 женщин, по переписи 1897 г.) слагается из армян (56 \%), адербейджанских татар (37,5 \%), курдов (5,5 \%) и русских (о,6 \%); остальные 0,4 \% приходятся на айсоров, греков, грузин, евреев и цыган. 55 \% армяно-григориан, 0,9 \% армян-католиков, $41 \%$ мусульман (36,7 \% шиитов, 4,3 \% суннитов), 1,7 \% езидов (часть курдов), 0,5 \% православных, о,4 \% сектантов и т.п. Армяне живут преимущественно в северо-западной части губернии, татары - в юговосточной, курды - в юго-западной. Большинство населения живет оседло; часть татар и в особенности курдов ведет полукочевой образ жизни. Главные занятия населения - земледелие и скотоводство» (Брокгауз-Ефрон, 1904: 12). Как видим, экономика и промышленность региона тоже были весьма отсталыми и, следовательно, особой нужды в образованности не было - важнее были сельскохозяйственные и животноводческие навыки. Однако для развития экономики и производства требовалось и развитие образования.

Рассмотрим подробнее структуру уездных училищ Эриванской губернии, располагавшихся в городах Эривань, Александрополь, Нахичевань. Целью их, согласно Положению 1853 года, было «1) предоставление детям всех состояний вообще (т.е. всех сословий - Авт.), вместе с средствами нравственного образования, возможности приобрести те сведения, которые, по образу жизни их, нуждам и занятиям, могут быть им наиболее полезны как в общественной жизни, так и для продолжения дальнейшего образования в гимназиях и 2) образование детей лиц всех свободных состояний для занятия должностей учителей первоначальных училищ и частных школ» (орфография и пунктуация источника сохранены - Авт.) (Положение от 29.10.1853: 51). Как видим, еще до отмены крепостного права в систему образования закладывались ее всесословность, а также подготовка педагогических кадров (но только для свободных сословий).

Во главе училища стоял штатный смотритель, который либо назначался из числа учителей данного училища («отличившихся ревностью к службе, хорошим поведением и знаниями»), либо человек с высшим образованием с имеющимся опытом административно-педагогической работы («служившие прежде по учебному ведомству или в таких должностях, где они смогли приобрести нужные для смотрительской должности сведения») (Положение от 29.10.1853: 52). К квалификационным требованиям учителя выдвигались высшее или среднее (гимназическое) образование. В качестве преподаваемых предметов в училище были «Закон Божий, русский язык и русская грамматика, местный язык, арифметика, краткая география всеобщая и русская, краткий очерк всеобщей, русской и местной истории, чистописание и «начальные понятия о геометрии» (Положение от 29.10.1853: 53).

В качестве дополнительных/факультативных предметов в уездных училищах, где учились дети потомственных и личных дворян, в зависимости от возможности финансирования преподавались «формы производства дел и судебного порядка с практическими упражнениями» и бухгалтерия (Положение от 29.10.1853: 53). Положение 1853 года обязывало штатного смотрителя справедливо распределять нагрузку: «все предметы распределяются между преподавателями сколь можно уравнительнее, что и возлагается на обязанность штатного смотрителя и директора училищ» (Положение от 29.10.1853: 53).

Первоначальное училище располагалось только в г. Ново-Баязете. В качестве учащихся допускались только дети мужского пола всех состояний не моложе 8 лет (Положение от 29.10.1853: 58).

Обучение в первоначальных училищах было не только всесословным, но и бесплатным. Этот тип училищ был одно- и двухклассным. В одноклассных училищах учили только основам вероисповедания (того вероисповедания, к которому принадлежали жители населенного пункта) и основам арифметики (первые четыре действия и «действия над отвлеченными и именованными числами»), русскому чтению, письму (включая освоение практических навыков разговорной русской речи), а также чтению и письму местного языка. Двухклассные училища включали в курс к названным дисциплинам еще и «Краткий Катехизис и Краткую Священную Историю» (укороченный курс православной религии и истории ее возникновения), краткую русскую грамматику, чистописание и более углубленно - арифметику (знания «о простых дробях и действиях над ними») (Положение от 29.10.1853: 58-59). Судя по штатному расписанию первоначального училища в г. Ново-Баязете, предполагаем, что оно было одноклассным.

По состоянию на конец 1884 года в Эриванской губернии действовали:

1. Мужская гимназия в г. Эривань (преобразована в гимназию 31 марта 1881 г.). Гимназия была 8-классной, имелся и один подготовительный. Общее число классов было 18 (10 обычных и 8 параллельных) (Отчет, 1884: 241). 
К 31 декабря 1884 года в гимназии училось 246 человек. Самыми многочисленными были дети представителей дворянского сословия (88 чел.), однако отрыв от других сословий в Эриванской губернии (в отличие, к примеру, от Тифлисской или Кутаисской губерний; см, напр., Mamadaliev et al., 2020a; Mamadaliev et al., 2020b; Mamadaliev et al., 2021e) был совсем невелик! Городских сословий было 69 учащихся, сельских сословий - 60 (!) чел., то есть превалирование дворян в средних учебных заведениях Эриванской губернии фактически отсутствовало, а крестьяне были представлены весьма сильно (в отличие от двух вышеуказанных губерний). Учеников из сословия духовенства было 32 чел., иностранных граждан - 2 чел. Таким образом, все сословия в целом были представлены одинаково, что выделяет в лучшую сторону Әриванскую губернию в сравнении с другими кавказскими территориями (иностранцы, разумеется, не в счет, так как русскими сословиями не являлись) (Отчет, 1884: 272).

По конфессиональному критерию большую часть учащихся составляют представители армяногригорианского вероисповедания (141 чел.), что вполне закономерно, учитывая, что половину населения губернии составляли армяне. Вторыми по счету являются представители православного христианства, и количество их меньше почти в 3 раза - 51 чел. Почти столько же представителей ислама - 49 чел. Остальные конфессии почти не представлены - протестанты (лютеране) - 4 чел., католики - 1 чел. (Отчет, 1884: 273).

По этническому критерию (который весьма соответствует конфессиональному) также вполне закономерно лидируют представители армянского этноса - 144 чел. На втором и третьем местах расположились соответственно татары (48 чел., статистические источники (см., напр., Сборник статистических сведений о Кавказе, 1896; Сборник сведений о Кавказе, 1871-1885; Брокгауз-Ефрон, 1896) называют их адербейджанскими татарами, совр. азербайджанцы - Авт.) и русские (43 чел.). Грузин (7 чел.), горцев (1 чел.) и европейцев (3 чел.) было совсем немного (Отчет, 1884: 273).

Фундаментальная библиотека гимназии насчитывала 4059 томов при 1824 названиях и стоимостью в 6435 руб., «подорожав» в сравнении с прошлым годом на сумму в 982 руб. Ученическая библиотека имела 687 томов с 449 названиями и стоимостью в 899 руб., став дороже за последний год на 66 руб. (Отчет, 1884: 242).

Несколько слов скажем о финансовой деятельности учреждения, так как этот критерий косвенно отражает его «ценность» в глазах администрации учебного округа. На содержание учреждения в отчетном году было потрачено 44716 руб., из них львиную долю составляло бюджетное финансирование в 37144 руб. (плюс 147 руб. на прибавочное (премиальное -Авт.) жалованье). Доходы от платы за обучение составили 4513 руб., от содержания частных воспитанников 1700 руб., от процентов с капитала 1212 руб. (Отчет, 1884: 244-245).

Израсходовано в 1884 году было 38980 руб. Основная статья расходов - содержание личного состава (25 891 руб.). На втором месте - содержание воспитанников пансиона (8 о28 руб.). Наем помещений обошелся в 2445 руб., хозяйственные расходы - в 2155 руб., приобретение учебных пособий для библиотек - 2 о76 руб., приобретение пособий служащим - 1410 руб., отчисления в Министерство народного просвещения - 517 руб., ремонт помещений - 370 руб., «премиальные» 147 руб., пособия учащимся - 90 руб., отчисления в Кавказский учебный округ - 89 руб., прочие расходы - 787 руб. (Отчет, 1884: 246-247). Средняя стоимость обучения за весь период составляла 140 руб., воспитания (т.е. с проживанием в пансионе) - 242 руб. (Отчет, 1884: 248). Ежегодная плата за обучение составляла 16-25 руб. (Отчет, 1884: 252).

2. Учительская семинария в г. Эривань (основана 8 ноября 1881 г.).

Семинария была 6-классной (не считая одного подготовительного). По состоянию на 31 декабря 1884 г. в ней имелось 7 классов (Отчет, 1884: 303).

Общее количество учащихся в семинарии к концу 1884 года составляло 78 чел., увеличившись в сравнении с 1883 годом на 11 чел. (Отчет, 1884: 334).

Дворян и представителей сельских сословий было примерно поровну - 30 и 23 учащихся соответственно. Чуть меньше было представителей городских сословий - 16 чел. Детей представителей духовенства было 8 чел., нижних чинов - 1 чел. (Отчет, 1884: 335).

По конфессиональному критерию больше половины составляли представители армяногригорианского христианства - 44 чел., 21 - представители православной религии, 13 - мусульмане (Отчет, 1884: 335). Представителей других конфессий не было.

По национальному критерию большинство было за представителями армянского этноса 44 чел. На втором месте с огромным отрывом были татары (азербайджане) - 13 чел., горцев 8, русских - 7, грузин - 3, европейцев - 3 (Отчет, 1884: 335).

Фундаментальная библиотека имела в своем составе 1671 том с 941 названием и стоимостью в 3101 руб., «подорожав» за год на 695 руб. Ученическая имела 1920 томов с 567названиями и стоимостью в 1636 руб., став дороже в 1884 отчетном году на 307 руб. (Отчет, 1884: 304).

3. Женская прогимназия в г. Эривань (основана 9 июля 1884 г.).

Учреждение, в отличие от других прогимназий округа, было трехклассным (не включая один подготовительный класс) (Отчет, 1884: 367). Плата за обучение составляла 36 руб. в год (Отчет, 1884: 376). 
Число учениц к 31 декабря 1884 г. составило 72 чел. Среди них превалировали дворянки 42 чел. На втором месте располагались представительницы городских сословий (26 чел.). Количество остальных сословий было ничтожно малым: духовенство - 1 чел., сельские сословия - 1 чел., нижних чинов - 2 чел. Такая ситуация объясняется, на наш взгляд, во-первых, достаточно высокой платой за обучение (которую не могли себе позволить крестьяне, нижние чины и бедные городские сословия) и, во-вторых, квотами на обучение дворянским детям (для увеличения степени их лояльности) (Отчет, 1884: 392).

Из общего числа учениц больше всего было представительниц армяно-григорианского вероисповедания (43 чел.), на втором месте с достаточно большим отрывом - православные христианки (25 чел.); количество остальных конфессий было крайне невелико - католичек 1 чел., «раскольников» - 1 чел., мусульманок - 2 чел. (Отчет, 1884: 393).

По национальному критерию наибольшее количество мест было у армянок (44 ученицы), на втором месте - русские (22 ученицы), представителей других этносов было очень мало: грузинок 2 чел., татарок (азербайджанок) - 2 чел. (Отчет, 1884: 393)

Информация о библиотечном фонде прогимназии отсутствует (Отчет, 1884: 369).

4. Три городских училища:

1) Александропольское (г. Александрополь, 1876 год основания). Обучение включало 3 класса. Подготовительный класс не предусматривался (Отчет, 1884: 423). Число учащихся к концу 1884 года - 156 чел. Детей дворян обучалось 19 чел., духовенства - 10 чел., сельских сословий - 30 чел., больше всего было представителей городских сословий - 97 чел. (Отчет, 1884: 440). По конфессиональному признаку на первом месте и с почти трехкратным отрывом были представители армяногригорианского христианства - 112 чел., на втором месте - православные христиане - 41 чел.; представителей других конфессий практически нет (мусульман - 2 чел., «евреев» (иудейское вероисповедание) - 1 чел.) (Отчет, 1884: 440). По этническому критерию на первом месте армяне 112 чел., на втором с огромным отрывом - русские - 38 чел.; других национальностей крайне мало: грузин - 3, татар - 2, евреев - 1 .

2) Ново-Баязетовское (г. Ново-Баязет, основано 1 июля 1880 года). Обучение включало 2 класса. Подготовительный класс не предусматривался (Отчет, 1884: 423). Число учащихся к концу 1884 года - 74 чел. Детей дворян обучалось 4 чел., духовенства - 7, сельских сословий - 11, больше всего было представителей городских сословий - 52 чел. (Отчет, 1884: 440). По конфессиональному признаку на первом месте с многократным отрывом шли представители армяно-григорианского христианства 67 чел., представителей других конфессий крайне мало (православных христиан - 2, мусульман - 5) (Отчет, 1884: 440). По этническому критерию абсолютное большинство у армян - 67 чел. (90 \%), татар - 5, русских - 1 (Отчет, 1884: 441).

3) Нахичеванское (г. Нахичевань, основано 6 июля 1879 года). Обучение включало 3 класса. Предусматривался один подготовительный класс (Отчет, 1884: 423). Число учащихся к концу 1884 года - 188 чел. Детей дворян обучалось 29 чел., духовенства - 13, сельских сословий - 32, нижних чинов - 3; традиционно для городских училищ больше всего было представителей городских сословий - 97 чел. (Отчет, 1884: 440). По конфессиональному признаку на первом месте с более чем двукратным отрывом были представители армяно-григорианского христианства - 128, мусульмане на втором месте - 51, православных христиан очень мало - 9 (Отчет, 1884: 440). Безусловно, конфессиональный критерий в Эриванской губернии всецело отражает критерий этнический. Что касается последнего, то армяне на первом месте с 128 учащимися, на втором месте с более чем двукратным отрывом татары - 51 чел., русских - всего 9 чел. (Отчет, 1884: 441).

5. Начальные училища - 14 шт. (к концу 1884 г., увеличившись за отчетный год на 3 шт.). Количество учащихся в них - 586 чел., из которых учащиеся мужского пола - 571 чел., женского 15 чел. (Отчет, 1884: 492; 512). Подобное гендерное соотношение следует признать традиционным для кавказских регионов, и Эриванская губерния не стала исключением. По сословному критерию превалируют дети представителей сельских сословий (340 чел.), на втором месте с более чем двукратным отрывом - представители городских сословий (132 чел.), на третьем - дети дворян и чиновников (71 чел.), на четвертом - дети духовенства (40 чел.) и совсем малое количество - дети нижних чинов (3 чел.) (Отчет, 1884: 514). По конфессиональному критерию большая часть представители армяно-григорианского христианства (285 чел.), на втором месте - мусульмане (212 чел.), православных христиан - 88 чел., раскольников - 1 чел. (Отчет, 1884: 514-515). По национальному составу больше всего среди учащихся было армян (285 чел.), на втором месте татары (азербайджанцы) (212), горцев - 40, евреев - 24, русских - 19, грузин - 5 (Отчет, 1884: 515).

В заключение отметим, что в сравнении с нижней хронологической границей в Эриванской губернии в образовательной сфере был сделан качественный скачок и в количественном, и в качественном выражении. Во-первых, появилось среднее образование (в виде гимназического образования как мужского, так и женского, а также учительские семинарии). Во-вторых, появилась сеть начальных училищ. Однако в сравнении, к примеру, с прибрежными кавказскими губерниями (Тифлисской, Кутаисской, Черноморской) количество учебных заведений на душу населения здесь было значительно ниже. Это, на наш взгляд, объясняется превалированием традиционных промыслов 
(сельское хозяйство и животноводство), которые не предъявляли больших требований к образованности населения, что отличало Эриванскую губернию от активно торгующих и промышленно развивающихся прибрежных губерний, где образование весьма ценилось и было востребовано.

\section{5. Заключение}

Подытоживая сказанное, отметим ключевые моменты, обозначенные выше:

1. Положение от 1853 года стало юридическим инструментом, который положил начало интеграции системы образования Эриванской губернии в имперскую.

2. В начале 1850-х годов (1853 г.) в губернии действовало только четыре учебных заведения: три уездных училища и одно первоначальное училище. Систему образования губернии объективно следует признать весьма слабой.

По состоянию на конец 1884 года в Эриванской губернии действовали одна мужская гимназия, одна женская прогимназия, одна учительская семинария, три городских училища и 14 начальных училищ.

В сравнении с началом 1850-х годов развитие системы образования имело не только количественный, но и качественный характер, в частности:

- появилась сеть образовательных учреждений среднего образования;

- появилась сеть начальных училищ.

3. По сословному признаку в средних учебных заведениях превалировали дворяне, однако представительство сельских слоев населения было весьма сильным (в отличие от других регионов), даже несмотря на начавшуюся политику контрреформизма с присущим ей ограничением доступа к образованию низшим сословиям. В низших и начальных учебных заведениях закономерно превалировали дети сельских и городских сословий.

4. По конфессиональному критерию было преобладание представителей армяногригорианского христианства, так как данный критерий был тесно связан с этническим - армян на территории губернии было чуть больше половины населения (52 \%). В зависимости от района на втором месте были либо православные христиане со значительным количеством русского населения (к примеру, в Александрополе), в некоторых районах - мусульмане с большим количеством тюркоязычного населения - «татар», т.е. современных азербайджанцев (к примеру, в Ново-Баязете или Нахичевани). Так или иначе конфессиональный критерий был прочно привязан к этническому.

5. Вместе с тем уровень развития образования в Эриванской губернии был значительно ниже, чем, к примеру, в прибрежных регионах Кавказского учебного округа - Тифлисской, Кутаисской, Черноморской губерниях. Количество учебных заведений на душу населения здесь было значительно ниже, то же самое касается и качественного критерия - количество средних учебных заведений было меньше. Такая ситуация, по нашему мнению, объясняется превалированием традиционных сельскохозяйственных и животноводческих промыслов, которые не предъявляли больших требований к образованности. Прибрежные черноморские губернии активно торговали через морские порты и бурно развивались в промышленном отношении, что объясняет большую востребованность в образованности населения. Однако по тому факту, что библиотечный фонд заведений закупался (и, соответственно, расширялся) значительными темпами, можно предположить, что власть планировала кардинально улучшить ситуацию с образованностью населения.

\section{Литература}

АКАК - Акты, собранные Кавказской комиссией. Т. 8. Тифлис, 1881.

Богоявленский, 1911 - Богоявленский A.A. Библиотечное дело в начальных училищах Кавказского учебного округа // Журнал Министерства народного просвещения. 1911. № 6.

Богоявленский, 1912а - Богоявленский A.A. Библиотечное дело в начальных училищах Кавказского учебного округа // Журнал Министерства народного просвещения. 1912. № 5.

Богоявленский, 1912b - Богоявленский A.A. Библиотечное дело в начальных училищах Кавказского учебного округа (продолжение) (Черноморская губерния в т.ч.) // Журнал Министерства народного просвещения. 1912. № 6.

Брокгауз-Ефрон, 1904 - Эриванская губерния // Энциклопедический словарь Брокгауза и Ефрона. T. XLI (81). СПб., 1904.

Воронов, 1857 - Воронов Н.И. Черноморские письма // Русский вестник. 1857. № 1, 3.

Всеобщая перепись населения, 1897 - Первая Всеобщая перепись населения Российской империи 1897 г. Том LXXI. Эриванская губерния / Под ред. Н.А. Тройницкого. СПб., 1905.

Гатагова, 1993 - Гатагова Л.С. Правительственная политика и народное образование на Кавказе в XIX в. М., 1993.

Зажаев, 1909 - Зажаев П. Городские училища по положению 1872 года в России и на Кавказе // На Кавказе. 1909. № 4 .

Зейдлиц, 1894 - Зейдлиц Н.К. Свод статистических данных о населении Закавказья, с полным алфавитным указателем городов и деревень края. Тифлис, 1894. 
Исторический обзор, 1902 - Исторический обзор деятельности Министерства народного просвещения. 1802-1902 / Сост. С.В. Рождественский. СПб., 1902.

Кобахидзе, 2015 - Кобахидзе Е.И. Законодательство 1840-1870-х гг. в области образования как фактор интеграции кавказской школы в российскую систему народного просвещения // Исторические, философские, политические и юридические науки, культурология и искусствоведение. Вопросы теории и практики. 2015. № 10. Ч. 3. С. 87-90.

Материалы по истории, 1942 - Материалы по истории осетинского народа: Сборник документов по истории завоевания осетин русским царизмом / Сост. В.С. Гальцев. Орджоникидзе, 1942. Т. II.

Модзалевский, 1880 - Модзалевский Л. Ход учебного дела в Кавказском крае с 1802 по 1880 год // Памятная книжка Кавказского учебного округа на 1880 год. Тифлис, 1880.

Народное образование, 1980 - Народное образование и педагогическая мысль России кануна и начала империализма (Малоисследованные проблемы и источники). Сб. научных трудов / Под ред. Э.Д. Днепрова. М., 1980.

Отчет, 1884 - Отчет попечителя Кавказского учебного округа «О состоянии учебных заведений» за 1885 г. Тифлис, 1885 .

Положение от 29.10.1853 - Положение «О Кавказском учебном округе и учебных заведениях» от 29 октября 1853 года // Журнал Министерства народного просвещения. СПб., 1853. № 80.

ПСЗРИ, 1911 - Полное собрание законов Российской империи. Собрание 3-е. Том XXVIII. 1908. СПб., 1911.

Сборник сведений о Кавказе, 1871-1885 - Сборник сведений о Кавказе / Под ред. Н.К. Зейдлица. Т. 1-9. Тифлис, 1871-1885.

Сборник статистических сведений, 1869 - Сборник статистических сведений о Кавказе / Сост.

Н.И. Воронов. Ч. 1. Тифлис, 1869.

Статистическое описание, 1835 - Статистическое описание Закавказского края / Сост.

О. Евецкий. В 2 ч. Ч. 1. СПб., 1835.

Штат КУО - «Штат Кавказского учебного округа», утв. Повелением ЕВ от 29 октября 1853 года // Журнал Министерства народного просвещения. СПб., 1853. № 80.

Cherkasov et al., 2020 - Cherkasov A.A., Koroleva L.A., Bratanovskii S.N. The System of Public Education on the Territory of the Black Sea Province in 1896-1917. Part 1 // Vestnik of Saint Petersburg University. History. 2020. 65 (3): 750-770.

Cherkasov et al., 2020a - Cherkasov A.A., Koroleva L.A., Bratanovskii S.N. The System of Public Education on the Territory of the Black Sea Province in 1896-1917. Part 2 // Vestnik of Saint Petersburg University. History. 2020. 65 (4): 1067-1084.

Cherkasov et al., 2020b - Cherkasov A.A., Bratanovskii S.N., Zimovets L.G. The System of Public Education in Terek Oblast in the Period 1860-1917. Part 1 // European Journal of Contemporary Education. 2020. 9(4): 963-970.

Cherkasov, 2011 - Cherkasov A.A. All-Russian Primary Education (1894-1917): Developmental Milestones // Social Evolution \& history. 2011. № 2 (10): 138-149.

Magsumov et al., 2018 - Magsumov T.A., Artemova S.F., Ustinova O.V., Vidishcheva E.V. (2018). Public education system in the Caucasus region in the 1850s: Unification and regulation of educational process // European Journal of Contemporary Education. 2018. 7(3): 598-607.

Magsumov et al., 2020 - Magsumov T.A., Korolev A.A., Ponomareva M.A., Zulfugarzade T.E. The System of Public Education in Kars Oblast in the Period 1878-1917. Part 1 // European Journal of Contemporary Education. 2020. 9(1): 221-234.

Magsumov et al., 2020a - Magsumov T.A., Korolev A.A., Ponomareva M.A., Zulfugarzade T.E. The System of Public Education in Kars Oblast in the Period 1878-1917. Part 1 // European Journal of Contemporary Education. 2020. 9(2): 459-472.

Mamadaliev et al., 2020a - Mamadaliev A.M., Karpukhin D.V., Svechnikova N.V., Médico A. The System of Public Education in Tiflis Governorate in the Period 1802-1917. Part 1 // European Journal of Contemporary Education. 2020. 9(1): 235-247.

Mamadaliev et al., 2020b - Mamadaliev A.M., Karpukhin D.V., Svechnikova N.V., Médico A. The System of Public Education in Tiflis Governorate in the Period 1802-1917. Part 2 // Bylye Gody. 2020. 56(2): 530-540.

Mamadaliev et al., 2020c - Mamadaliev A.M., Karpukhin D.V., Svechnikova N.V., Médico A. The System of Public Education in Tiflis Governorate in the Period 1802-1917. Part 3 // Bylye Gody. 2020. 57(3): 1065-1084.

Mamadaliev et al., 2020d - Mamadaliev A.M., Karpukhin D.V., Svechnikova N.V., Médico A. (2020). The System of Public Education in Tiflis Governorate in the Period 1802-1917. Part 4 // Bylye Gody. 2020. 58(4): 2409-2426.

Mamadaliev et al., 2021e - Mamadaliev A.M., Karpukhin D.V., Svechnikova N.V., Koroleva L.A. The System of Public Education in the Kutaisi Province in 1846-1917. Part 1 // Bylye Gody. 2021. 16(1): 169-181. 
Mamadaliev et al., 2021f - Mamadaliev A.M., Karpukhin D.V., Svechnikova N.V., Koroleva L.A. The System of Public Education in the Kutaisi Province in 1846-1917. Part 2 // Bylye Gody. 2021. 16(2): 699-716.

Mamadaliev et al., 2021g - Mamadaliev A.M., Novitskaya L.Yu., Svechnikova N.V., Koroleva L.A. The System of Public Education in the Kutaisi Province in 1846-1917. Part 3 // Bylye Gody. 2021. 16(3): 1191-1202.

Molchanova et al., 2019 - Molchanova V.S., Balanyuk L.L., Vidishcheva E.V., Potapova I.I. The Development of Primary Education on the Cossack Territories in 1803-1917 years (on the Example of the Kuban Region). Part 1 // Bylye Gody. 2019. 53(3): 1049-1058.

Molchanova et al., 2019a - Molchanova V.S., Balanyuk L.L., Vidishcheva E.V., Potapova I.I. The Development of Primary Education on the Cossack Territories in 1803-1917 years (on the Example of the Kuban Region). Part 2 // Bylye Gody. 2019. 54(2): 1524-1536.

Molchanova et al., 2020 - Molchanova V.S., Balanyuk L.L., Vidishcheva E.V., Potapova I.I. The Development of Primary Education on the Cossack Territories in 1803-1917 years (on the Example of the Kuban Region). Part 3 // Bylye Gody. 2020. 55(1): 88-104.

Natolochnaya et al., 2016 - Natolochnaya O.V., Kryukova N.I., Buslaev S.I. The development of the public education system in the Caucasus in the pre-revolutionary period (1905-1917 years) // Bylye Gody. 2016. Vol. 39. Is. 1. 222-228.

Natolochnaya et al., 2018 - Natolochnaya O.V., Miku N.V., Zulfugarzade T.E., Médico A. Highland schools in the Caucasus: Historical background // European Journal of Contemporary Education. 2018. 7(3): 608-614.

Natolochnaya et al., 2020 - Natolochnaya O.V., Zimovets L.G., Allalyev R.M., Svechnikov V.A. (2020). The System of Public Education in Stavropol Governorate in the Period 1804-1917. Part $1 / /$ European Journal of Contemporary Education. 2020. 9(2): 473-480.

Natolochnaya et al., 2020a - Natolochnaya O.V., Makarov Y.N., Allalyev R.M., Svechnikov V.A. The System of Public Education in Stavropol Governorate in the Period 1804-1917. Part 2 // European Journal of Contemporary Education. 2020. 9(3): 679-688.

Natolochnaya et al., 2020b - Natolochnaya O.V., Allalyev R.M., Svechnikov V.A., Ivantsov V.G. The System of Public Education in Stavropol Governorate in the Period 1804-1917. Part 3 // European Journal of Contemporary Education. 2020. 9(4): 984-992.

Shevchenko et al., 2016 - Shevchenko N.A., Vidishcheva E.V., Emelyanova O.V. The Establishment of the System of Public Education in the Caucasus (1802-1917 years): the Characteristic Features // Bylye Gody. 2016. Vol. 40. Is. 2. 363-372.

\section{References}

AKAK - Akty, sobrannye Kavkazskoi komissiei [Acts collected by the Caucasian Commission]. T. 8 . Tiflis, 1881. [in Russian]

Bogoyavlenskii, 1911 - Bogoyavlenskii, A.A. (1911). Bibliotechnoe delo v nachal'nykh uchilishchakh Kavkazskogo uchebnogo okruga [Librarianship in primary schools of the Caucasian educational district]. Zhurnal Ministerstva narodnogo prosveshcheniya. 6. [in Russian]

Bogoyavlenskii, 1912a - Bogoyavlenskii, A.A. (1912). Bibliotechnoe delo v nachal'nykh uchilishchakh Kavkazskogo uchebnogo okruga [Librarianship in primary schools of the Caucasian educational district]. Zhurnal Ministerstva narodnogo prosveshcheniya. 1912. 5. [in Russian]

Bogoyavlenskii, 1912b - Bogoyavlenskii, A.A. (1912). Bibliotechnoe delo v nachal'nykh uchilishchakh Kavkazskogo uchebnogo okruga (prodolzhenie) (Chernomorskaya guberniya $\mathrm{v}$ t.ch.) [Librarianship in primary schools of the Caucasian educational district (continued) (Black Sea province including)]. Zhurnal Ministerstva narodnogo prosveshcheniya. 6. [in Russian]

Brokgauz-Efron, 1904 - Erivanskaya guberniya [Erivan province]. Entsiklopedicheskii slovar' Brokgauza i Efrona. T. XLI (81). SPb., 1904. [in Russian]

Cherkasov et al., 2020 - Cherkasov, A.A., Koroleva, L.A., Bratanovskii, S.N. (2020). The System of Public Education on the Territory of the Black Sea Province in 1896-1917. Part 1. Vestnik of Saint Petersburg University. History. 65 (3): 750-770.

Cherkasov et al., 2020a - Cherkasov, A.A., Koroleva, L.A., Bratanovskii, S.N. (2020). The System of Public Education on the Territory of the Black Sea Province in 1896-1917. Part 2. Vestnik of Saint Petersburg University. History. 65(4): 1067-1084.

Cherkasov et al., 2020b - Cherkasov, A.A., Bratanovskii, S.N., Zimovets, L.G. (2020). The System of Public Education in Terek Oblast in the Period 1860-1917. Part 1. European Journal of Contemporary Education. 9(4): 963-970.

Cherkasov, 2011 - Cherkasov, A.A. All-Russian Primary Education (1894-1917): Developmental Milestones. Social Evolution \& history. 2(10): 138-149.

Gatagova, 1993 - Gatagova, L.S. (1993). Pravitel'stvennaya politika i narodnoe obrazovanie na Kavkaze v XIX v. [Government policy and public education in the Caucasus in the 19th century]. M. [in Russian] 
Istoricheskii obzor, 1902 - Istoricheskii obzor deyatel'nosti Ministerstva narodnogo prosveshcheniya. 1802-1902 [Historical review of the activities of the Ministry of Public Education. 1802-1902]. Sost. S.V. Rozhdestvenskii. SPb., 1902. [in Russian]

Kobakhidze, 2015 - Kobakhidze, E.I. (2015). Zakonodatel'stvo 1840-1870-kh gg. v oblasti obrazovaniya kak faktor integratsii kavkazskoi shkoly v rossiiskuyu sistemu narodnogo prosveshcheniya [Legislation of the 1840-1870 in the field of education as a factor of integration of the Caucasian school into the Russian system of public education]. Istoricheskie, filosofskie, politicheskie $i$ yuridicheskie nauki, kul'turologiya i iskusstvovedenie. Voprosy teorii i praktiki. 10. Ch. 3. Pp. 87-90. [in Russian]

Magsumov et al., 2018 - Magsumov, T.A., Artemova, S.F., Ustinova, O.V., Vidishcheva, E.V. (2018). Public education system in the Caucasus region in the 1850s: Unification and regulation of educational process. European Journal of Contemporary Education. 7(3): 598-607.

Magsumov et al., 2020 - Magsumov, T.A., Korolev, A.A., Ponomareva, M.A., Zulfugarzade, T.E. (2020). The System of Public Education in Kars Oblast in the Period 1878-1917. Part 1. European Journal of Contemporary Education. 9(1): 221-234.

Magsumov et al., 2020a - Magsumov, T.A., Korolev, A.A., Ponomareva, M.A., Zulfugarzade, T.E. (2020). The System of Public Education in Kars Oblast in the Period 1878-1917. Part 1. European Journal of Contemporary Education. 9(2): 459-472.

Mamadaliev et al., 2020a - Mamadaliev, A.M., Karpukhin, D.V., Svechnikova, N.V., Médico, A. (2020). The System of Public Education in Tiflis Governorate in the Period 1802-1917. Part 1. European Journal of Contemporary Education. 9(1): 235-247.

Mamadaliev et al., 2020b - Mamadaliev, A.M., Karpukhin, D.V., Svechnikova, N.V., Médico, A. (2020). The System of Public Education in Tiflis Governorate in the Period 1802-1917. Part 2. Bylye Gody. 56(2): 530-540.

Mamadaliev et al., 2020c - Mamadaliev, A.M., Karpukhin, D.V., Svechnikova, N.V., Médico, A. (2020). The System of Public Education in Tiflis Governorate in the Period 1802-1917. Part 3. Bylye Gody. 57(3): 1065-1084.

Mamadaliev et al., 2020d - Mamadaliev, A.M., Karpukhin, D.V., Svechnikova, N.V., Médico, A. (2020). The System of Public Education in Tiflis Governorate in the Period 1802-1917. Part 4. Bylye Gody. 58(4): 2409-2426.

Mamadaliev et al., 2021e - Mamadaliev, A.M., Karpukhin, D.V., Svechnikova, N.V., Koroleva, L.A. (2021). The System of Public Education in the Kutaisi Province in 1846-1917. Part 1. Bylye Gody. 16(1): 169-181.

Mamadaliev et al., 2021f - Mamadaliev, A.M., Karpukhin, D.V., Svechnikova, N.V., Koroleva, L.A. (2021). The System of Public Education in the Kutaisi Province in 1846-1917. Part 2. Bylye Gody. 16(2): $699-716$.

Mamadaliev et al., 2021g - Mamadaliev, A.M., Novitskaya, L.Yu., Svechnikova, N.V., Koroleva, L.A. The System of Public Education in the Kutaisi Province in 1846-1917. Part 3. Bylye Gody. 16(3): 1191-1202.

Materialy po istorii, 1942 - Materialy po istorii osetinskogo naroda: Sbornik dokumentov po istorii zavoevaniya osetin russkim tsarizmom [Materials on the history of the Ossetian people: Collection of documents on the history of the conquest of the Ossetians by Russian tsarism]. Sost. V.S. Gal'tsev. Ordzhonikidze, 1942. T. II. [in Russian]

Modzalevskii, 1880 - Modzalevskii, L. (1880). Khod uchebnogo dela v Kavkazskom krae s 1802 po 1880 god [The course of educational affairs in the Caucasian region from 1802 to 1880]. Pamyatnaya knizhka Kavkazskogo uchebnogo okruga na 1880 god. Tiflis, 1880. [in Russian]

Molchanova et al., 2019 - Molchanova, V.S., Balanyuk, L.L., Vidishcheva, E.V., Potapova, I.I. (2020). The Development of Primary Education on the Cossack Territories in 1803-1917 years (on the Example of the Kuban Region). Part 1. Bylye Gody. 53(3): 1049-1058.

Molchanova et al., 2019a - Molchanova, V.S., Balanyuk, L.L., Vidishcheva, E.V., Potapova, I.I. (2020). The Development of Primary Education on the Cossack Territories in 1803-1917 years (on the Example of the Kuban Region). Part 2. Bylye Gody. 54(2): 1524-1536.

Molchanova et al., 2020 - Molchanova, V.S., Balanyuk, L.L., Vidishcheva, E.V., Potapova, I.I. (2020).

The Development of Primary Education on the Cossack Territories in 1803-1917 years (on the Example of the Kuban Region). Part 3. Bylye Gody. 55(1): 88-104.

Narodnoe obrazovanie, 1980 - Narodnoe obrazovanie i pedagogicheskaya mysl' Rossii kanuna i nachala imperializma (Maloissledovannye problemy i istochniki) [Public education and pedagogical thought in Russia on the eve and the beginning of imperialism (Little researched problems and sources)]. Sb. nauchnykh trudov. Pod red. E.D. Dneprova. M., 1980. [in Russian]

Natolochnaya et al., 2016 - Natolochnaya, O.V., Kryukova, N.I., Buslaev, S.I. (2016). The development of the public education system in the Caucasus in the pre-revolutionary period (1905-1917 years). Bylye Gody. 39(1): 222-228.

Natolochnaya et al., 2018 - Natolochnaya, O.V., Miku, N.V., Zulfugarzade, T.E., Médico, A. (2018). Highland schools in the Caucasus: Historical background. European Journal of Contemporary Education. $7(3): 608-614$. 
Natolochnaya et al., 2020 - Natolochnaya, O.V., Zimovets, L.G., Allalyev, R.M., Svechnikov, V.A. (2020). The System of Public Education in Stavropol Governorate in the Period 1804-1917. Part 1. European Journal of Contemporary Education. 9(2): 473-480.

Natolochnaya et al., 2020a - Natolochnaya, O.V., Makarov, Y.N., Allalyev, R.M., Svechnikov, V.A. (2020). The System of Public Education in Stavropol Governorate in the Period 1804-1917. Part 2. European Journal of Contemporary Education. 9(3): 679-688.

Natolochnaya et al., 2020b - Natolochnaya, O.V., Allalyev, R.M., Svechnikov, V.A., Ivantsov, V.G. (2020). The System of Public Education in Stavropol Governorate in the Period 1804-1917. Part 3. European Journal of Contemporary Education. 9(4): 984-992.

Otchet, 1884 - Otchet popechitelya Kavkazskogo uchebnogo okruga «O sostoyanii uchebnykh zavedenii» za 1885 g. [Report of the trustee of the Caucasian educational district "On the state of educational institutions" for 1885]. Tiflis, 1885 . [in Russian]

Polozhenie ot 29.10.1853 - Polozhenie «O Kavkazskom uchebnom okruge i uchebnykh zavedeniyakh» ot 29 oktyabrya 1853 goda [Regulations "On the Caucasian educational district and educational institutions" of October 29, 1853]. Zhurnal Ministerstva narodnogo prosveshcheniya. SPb., 1853. № 80. [in Russian]

PSZRI, 1911 - Polnoe sobranie zakonov Rossiiskoi imperii [Complete collection of laws of the Russian Empire]. Sobranie 3-e. Tom XXVIII. 1908. SPb., 1911. [in Russian]

Sbornik statisticheskikh svedenii, 1869 - Sbornik statisticheskikh svedenii o Kavkaze [Collection of statistical information about the Caucasus]. Sost. N.I. Voronov. Ch. 1. Tiflis, 1869. [in Russian]

Sbornik svedenii o Kavkaze, 1871-1885 - Sbornik svedenii o Kavkaze [Collection of information about the Caucasus]. Pod red. N.K. Zeidlitsa. T. 1-9. Tiflis, 1871-1885. [in Russian]

Shevchenko et al., 2016 - Shevchenko, N.A., Vidishcheva, E.V., Emelyanova, O.V. (2016). The Establishment of the System of Public Education in the Caucasus (1802-1917 years): the Characteristic Features. Bylye Gody. 40(2). 363-372.

Shtat KUO - «Shtat Kavkazskogo uchebnogo okruga», utv. Poveleniem EV ot 29 oktyabrya 1853 goda ["Staff of the Caucasian educational district", approved. By order of the EB of October 29, 1853]. Zhurnal Ministerstva narodnogo prosveshcheniya. SPb., 1853. № 80. [in Russian]

Statisticheskoe opisanie, 1835 - Statisticheskoe opisanie Zakavkazskogo kraya [Statistical description of the Transcaucasian region]. Sost. O. Evetskii. V 2 ch. Ch. 1. SPb., 1835. [in Russian]

Voronov, 1857 - Voronov, N.I. (1857). Chernomorskie pis'ma [Black Sea Letters]. Russkii vestnik. 1, 3. [in Russian]

Vseobshchaya perepis' naseleniya, 1897 - Pervaya Vseobshchaya perepis' naseleniya Rossiiskoi imperii 1897 g. [The First General Census of the Population of the Russian Empire in 1897]. Tom LXXI. Erivanskaya guberniya. Pod red. N.A. Troinitskogo. SPb., 1905. [in Russian]

Zazhaev, 1909 - Zazhaev, P. (1909). Gorodskie uchilishcha po polozheniyu 1872 goda v Rossii i na Kavkaze [Municipal schools according to the 1872 situation in Russia and the Caucasus]. Na Kavkaze. 4. [in Russian]

Zeidlits, 1894 - Zeidlits, N.K. (1894). Svod statisticheskikh dannykh o naselenii Zakavkaz'ya, s polnym alfavitnym ukazatelem gorodov i dereven' kraya [A set of statistical data on the population of Transcaucasia, with a complete alphabetical index of towns and villages in the region]. Tiflis. [in Russian]

\section{Система народного образования в Эриванской губернии 1849-1917 гг. Часть 1}

Анвар Мирзахматович Мамадалиев а, b, * , Варвара Владимировна Богдан с, Наталья Викторовна Свечникова ${ }^{\mathrm{d}}$, Александр Николаевич Волков е

а Черкас глобальный университет, Вашингтон, США

b Волгоградский государственный университет, Волгоград, Российская Федерация

c Юго-Западный государственный университет, Курск, Российская Федерация

d Российский экономический университет им. Плеханова, Москва, Российская Федерация

е Сочинский государственный университет, Сочи, Российская Федерация

Аннотация. Серия из трех статей посвящена изучению системы образования в Эриванской губернии Российский империи в период с 1849 по 1917 годы. Данная статья является первой (и своего рода вводной) частью, в которой анализируется период с 1849 (год образования губернии) по 1884 годы, а также источники и историография исследуемого нами вопроса.

В работе рассматриваются природно-климатические, социальные и экономические особенности региона, а также процесс становления системы образования губернии и ее интеграция в общероссийскую. Отдельно анализируются типы учебных заведений (средние, низшие, начальные),

\footnotetext{
${ }^{*}$ Корреспондирующий автор

Адреса электронной почты: anvarm@mail.ru (А.М. Мамадалиев) 
а также библиотечный фонд средних учебных заведений (как один из важных критериев развития данного типа учреждений).

Основным источником послужили отчеты попечителей Кавказского учебного округа, в которых приведен подробнейший статистический материал о деятельности каждого типа учреждений. Также в качестве источников были использованы Положение «О Кавказском учебном округе и учебных заведениях» от 29 октября 1853 года, Акты Кавказской географической комиссии, Собрания законов Российской империи и др.

В работе также сделан краткий библиографический анализ дореволюционных, советских и современных трудов, посвященных развитию системы образования в Эриванской губернии в составе Российской империи.

По результатам исследования были сделаны выводы о том, что до принятия Положения от 1853 года система образования в Эриванской губернии объективно была крайне слабой: действовало лишь 4 учебных заведения низшего уровня. К концу 1884 года в губернии действовали 3 средних, 3 низших и 14 начальных учебных заведений. Вместе с тем в сравнении с прибрежными черноморскими губерниями (Тифлисской, Кутаисской, Черноморской) количество учебных заведений на душу населения все еще оставалось небольшим, а система образования, соответственно, неразвитой. Это можно объяснить превалированием традиционных промыслов, которые не предъявляли серьезных требований к образованности.

Ключевые слова: система народного образования, Эриванская губерния, Кавказский учебный округ, 1849-1884 гг. 